\title{
Vegetation Responses to Long-term Sheep Grazing on Mountain Ranges
}

\author{
JAMES E. BOWNS AND CALVIN F. BAGLEY
}

\begin{abstract}
Some high-elevation summer ranges in southwestern Utah are characterized by a dominance of grass and low-value forbs. A reference area of forb dominance provides a striking contrast to these grass ranges. The reference area has a greater number of total species and a greater number of forbs. Production (above-ground live biomass) is nearly 2 times as great in the reference area as in the surrounding pastures. Production of desirable species in the reference area is greater than the production of desirables, intermediates, and least desirables in the surrounding pastures. It is suggested that the grass dominance on these ranges is due to a long and persistent history of exclusive sheep grazing.
\end{abstract}

Major vegetation changes have occurred over much of the Intermountain West as a result of livestock grazing (Cottam 1947). In many cases presettlement vegetation is difficult or impossible to reconstruct, and long-term grazing by livestock has induced significant changes in vegetation.

A typical summer sheep range in southwestern Utah, known as Cedar Mountain, is characterized by a predominance of grasses and lacks desirable forbs and shrubs. This area is similar, in many respects to the Wasatch Plateau in central Utah, where Ellison (1954) described grass-dominated communities on sheep ranges and forb-dominated communities on cattle ranges. He proposed that much of the original (climax) vegetation of that area was an upland herb association dominated by tall mesic forbs, grasses, and sedges.

Livestock have grazed Cedar Mountain since the late 1860's, but sheep have grazed there almost exclusively since the late 1890 's (Jones and Jones 1972). The main interest of this study is a 60-acre reference area known locally as the Munford Pasture, which was fenced in the 1920's and grazed differently than the surrounding area since that time (Fig. 1).

The Munford Pasture, with its dominance of tall forbs, contrasts sharply with the surrounding grass-dominated pastures. This reference area has been, and is presently, lightly grazed by a few young cattle and saddle horses, and on rare occasions by sheep in late summer. Since the reference area has received some grazing it is not in pristine condition, but we feel that it can be considered potential or near potential natural vegetation and should be used as a benchmark area for judging range condition and the impact of

Authors are professor and graduate research assistant, Department of Range Science, Utah State University, Logan 84322.

Journal Article No. 3034, Utah State University Agricultural Experiment Station. Manuscript accepted 1 April 1986.

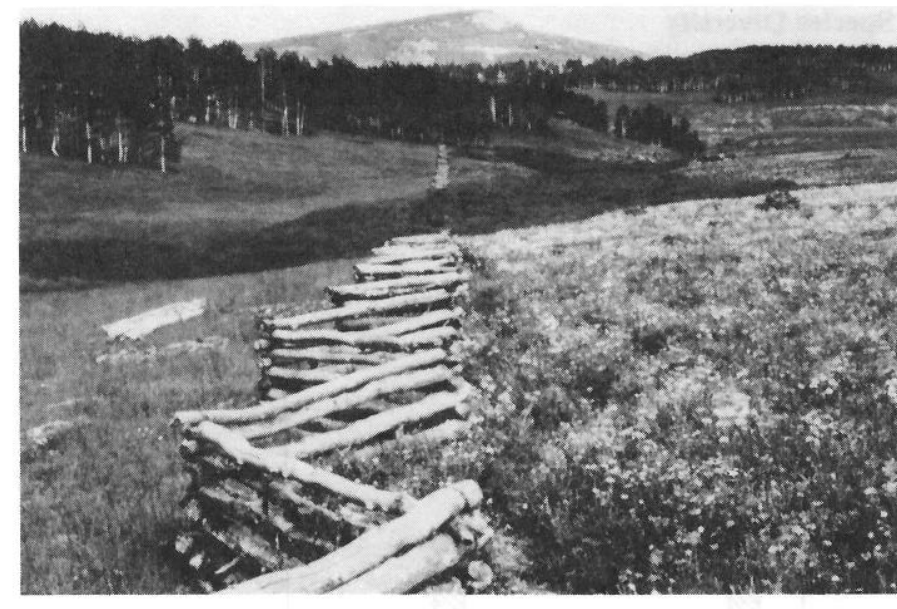

Fig. 1. Fence line view contrasting forb dominance in the reference area (right) with grass dominance in the sheep-grazed pasture (left).

prolonged sheep grazing on similar sites. Our main objective in this study was to evaluate the difference between the reference area and the sheep-grazed pastures and to characterize the vegetation in relation to past and current grazing practices.

\section{Study Area, Methods and Procedures}

Our study was located on privately owned land at an elevation of $2,800 \mathrm{~m}$ (9,200 feet) approximately $27 \mathrm{~km}$ ( 17 miles) southeast of Cedar City, Utah. Sheep-grazed pastures in the immediate area are characterized by aspen or open grassland. Soils are described as Argic Pachic Cryoborolls, fine montmorillontic faim clay loam, 2-15\% slope. (Soil Conservation Service, Draft Iron-Washington Survey Area). The grassland types are currently dominated by Letterman needlegrass (Stipa lettermani), and Kentucky bluegrass (Poa pratensis) with lesser amounts of mountain brome (Bromus carinatus), and slender wheatgrass (Agropyron trachycaulum). Shrubs, except along riparian zones, are rare, and desirable forbs are inconspicuous and rare in relation to grasses. The most common forbs on the sheep-grazed sites are western yarrow (Achillea millefolium), thickstem aster (Aster integrifolius), lambstongue senecio (Senecio integerrimus), dandelion (Taraxacum officinale), knotweed (Polygonum douglasii), and the extremely undesirable 
tarweed (Madia glomerata).

Forty $0.3 \mathrm{~m}$ by $0.6 \mathrm{~m}$ ( $1 \mathrm{ft}$ by $2 \mathrm{ft}$ ) plots were sampled within the reference area and 40 plots within an adjacent sheep-grazed area. Sampling occurred during August at peak live biomass. Plants in each plot were counted, clipped, weighed, and data were converted to air-dry weights. Each plot was systematically located along 4 randomly located transects. Transects were located in close proximity to boundary fences to minimize site differences, but at a great enough distance to minimize any effect due to fences.

Production (above-ground live biomass) and density were determined for each species encountered. Each species was characterized as desirable, intermediate, or least desirable in accordance with U.S. Forest Service guidelines (U.S. Forest Service 1969). Characterizing species according to these desirability classes was done in order to present the data in a manner useful to individuals interested in and responsible for managing similar ranges. Plant nomenclature follows Welsh and Moore (1973).

Analysis of variance was used to separate treatment means. Differences were tested at the $5 \%$ level of probability. (Dowdy and Wearden 1983).

\section{Results and Discussion}

The striking visual difference between the 2 areas is the predominance of forbs, the greater number of species, and higher biomass in the reference area compared to the sheep-grazed pasture.

\section{Species Diversity}

Species diversity or species richness was much greater in the reference area than in the sheep-grazed pasture. Within the reference area 33 species were encountered. Forbs dominated the reference area with $29(88 \%)$ species while only $4(12 \%)$ grass species were encountered. In the adjacent sheep-grazed pasture only 18 species were encountered, which included $13(72 \%)$ forbs and 5 (28\%) grasses (Fig. 2).
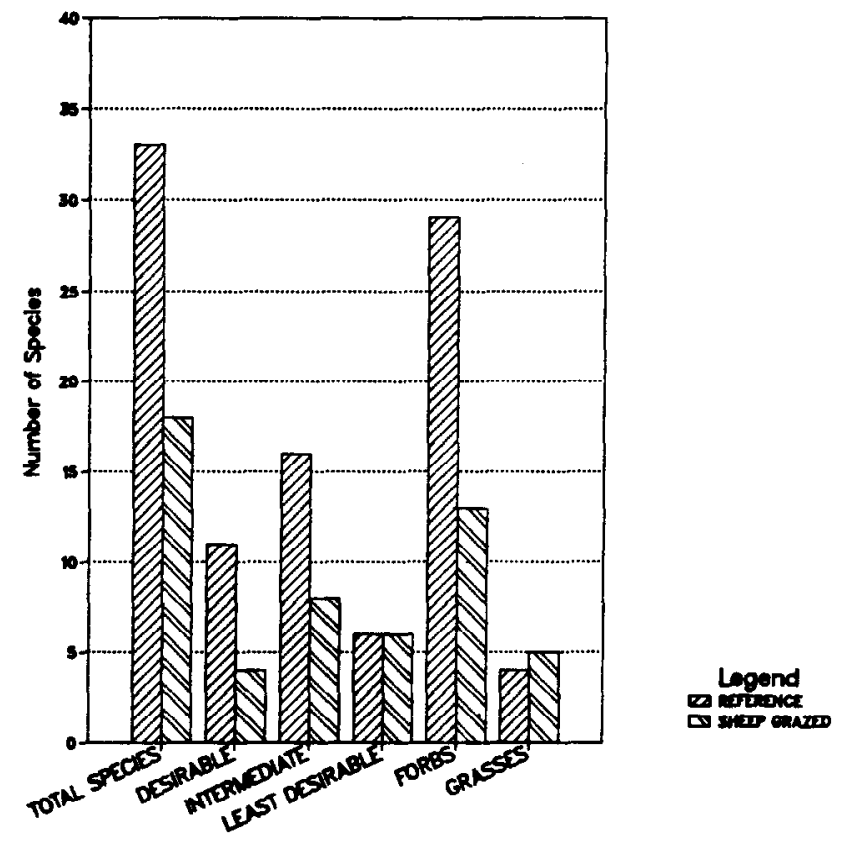

Fig. 2. Species diversity or species richness of the sheep-grazed and reference areas.

Species categorized as desirable, intermediate, or least desirable differed between the 2 areas. Within the reference area 11 (33\%) species were classified as desirables, $16(49 \%)$ were intermediates, and $6(18 \%)$ least desirables. Within the sheep-grazed pasture only $4(22 \%)$ species were rated as desirable, 3 of these being grasses, 8
$(44 \%)$ species were intermediate, and $6(33 \%)$ least desirable (Fig. 2).

\section{Above-ground Biomass}

Total above-ground biomass was 1.9 times greater $(P<0.05)$ in the reference area than in the sheep-grazed pasture. In the reference area desirable species contributed $59 \%(1,689 \mathrm{~kg} / \mathrm{ha})$, intermediates $39 \%(1,115 \mathrm{~kg} / \mathrm{ha})$, and least desirables $1 \%(40 \mathrm{~kg} / \mathrm{ha})$ to the

Table 1. Above ground air dry biomass (kg/ha) of individual species and deairability classes in the sheep-enzed and reference areas.

\begin{tabular}{|c|c|c|c|c|}
\hline & \multicolumn{2}{|c|}{ Sheep-grazed } & \multicolumn{2}{|c|}{ Reference } \\
\hline & $\mathrm{kg} / \mathrm{ha}$ & $\begin{array}{c}\text { Percent } \\
\text { of } \\
\text { total }\end{array}$ & $\mathrm{kg} / \mathrm{ha}$ & $\begin{array}{c}\text { Percent } \\
\text { of } \\
\text { total }\end{array}$ \\
\hline $\begin{array}{l}\text { Desirable } \\
\text { Agropyron trachycaulum } \\
\text { Bromus carinatus } \\
\text { Melica bulbosa } \\
\text { Agoseris glauca } \\
\text { Geranium fremontii } \\
\text { Lathyrus leucanthus } \\
\text { Ligusticum porteri } \\
\text { Penstemon rydbergii } \\
\text { P. leiophyllus } \\
\text { Potentilla gracilis } \\
\text { Vicia americana } \\
\text { Subtotal }\end{array}$ & $\begin{array}{c}22 \\
150 \\
0.5\end{array}$ & $\begin{array}{l}1.5 \\
10.1 \\
<1\end{array}$ & $\begin{array}{r}9 \\
27 \\
74 \\
684 \\
8 \\
762 \\
3 \\
8 \\
2 \\
38 \\
1689\end{array}$ & $\begin{array}{c}<1 \\
<1 \\
\\
2.6 \\
24.0 \\
<1 \\
26.8 \\
<1 \\
<1 \\
<1 \\
1.3 \\
59.4\end{array}$ \\
\hline $\begin{array}{l}\text { Intermediate } \\
\text { Poa pratensis } \\
\text { Stipa lettermani } \\
\text { Achillea millefolium } \\
\text { Artemisia dracunculus } \\
\text { A. ludoviciana } \\
\text { Aster integrifolius } \\
\text { Delphinium nelsoni } \\
\text { Erigeron speciosus } \\
\text { Hydrophyllum occidentale } \\
\text { Oenothera flava } \\
\text { Potentlla glandulosa } \\
\text { Solidago decumbens } \\
\text { Taraxacum officinale } \\
\text { Trifolium longipes } \\
\text { Viguiera multiflora } \\
\text { Viola spp. } \\
\text { Subtotal }\end{array}$ & $\begin{array}{c}303 \\
610 \\
42 \\
\\
7 \\
57 \\
0.8\end{array}$ & $\begin{array}{r}20.5 \\
41.3 \\
2.8 \\
<1 \\
3.9 \\
<1\end{array}$ & $\begin{array}{r}312 \\
117 \\
58 \\
22 \\
187 \\
84 \\
1 \\
26 \\
11 \\
\\
1 \\
23 \\
9 \\
5 \\
257 \\
2 \\
1115\end{array}$ & $\begin{array}{c}11.0 \\
4.1 \\
2.0 \\
<1 \\
6.6 \\
3.0 \\
<1 \\
<1 \\
<1 \\
<1 \\
<1 \\
<1 \\
<1 \\
9.0 \\
<1 \\
40.0\end{array}$ \\
\hline $\begin{array}{l}\text { Least Desirable } \\
\text { Androsace septentrionalis } \\
\text { Collomia linearis } \\
\text { Erigeron flagellaris } \\
\text { Madia glomerata } \\
\text { Polygonum douglasii } \\
\text { Senecio integerrimus } \\
\text { Stellaria jamesiana } \\
\text { Thelypodium sagittatum } \\
\text { Tragopogon dubius } \\
\text { Subtotal } \\
\text { Total aboveground biomass }\end{array}$ & $\begin{array}{r}0.5 \\
0.5 \\
6 \\
243 \\
23 \\
5\end{array}$ & $\begin{array}{c}<1 \\
<1 \\
<1 \\
16.4 \\
1.6 \\
<1\end{array}$ & $\begin{array}{c}2 \\
\\
0.5 \\
9 \\
\\
21 \\
0.2 \\
7 \\
39.7 \\
2844\end{array}$ & $\begin{array}{c}<1 \\
<1 \\
<1 \\
<1 \\
<1 \\
<1 \\
1.4 \\
100.0\end{array}$ \\
\hline
\end{tabular}

total above ground biomass (Table 1, Fig. 3). Forbs contributed $84 \%(2,379 \mathrm{~kg} / \mathrm{ha})$ and grasses $16 \%$ (465 kg/ha) (Fig. 4).

Desirable species alone in the reference area produced 1.14 times more above-ground biomass than the total of all categories or species in the sheep-grazed pasture. Desirables in the reference area outproduced desirables in the sheep-grazed pasture by 9.8 times. Production of intermediate species was comparable in the 2 areas, but least desirables in the sheep-grazed pasture significantly outproduced those in the reference area (Table 1, Fig. 3).

Geranium fremontii and Ligusticum porteri were the dominant forbs in the reference area. These 2 forbs contributed $51 \%$ to the 

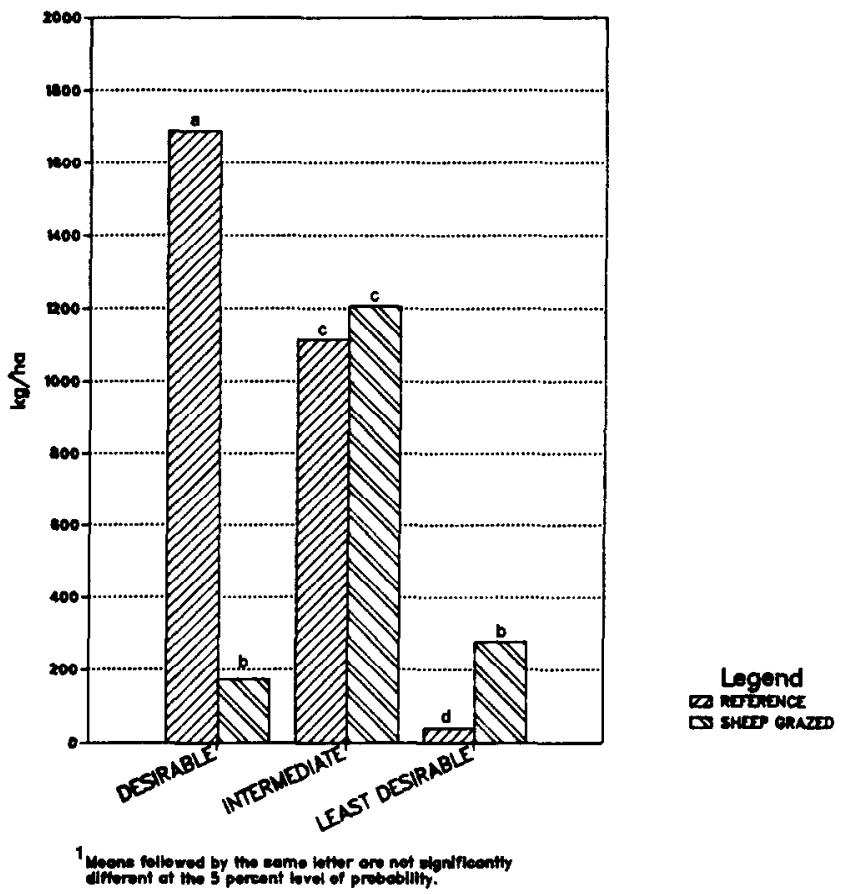

Fig. 3. Above-ground air dry biomass $(\mathrm{kg} / \mathrm{ha})$ by desirability classes in the sheep-grazed and reference areas.

total above-ground biomass. Neither species was encountered nor observed in the sheep-grazed pasture (Table 1). Several other forbs listed in Table 1 were encountered in the reference area but not in the sheep-grazed pasture. This pattern suggests that these forbs have decreased under sheep use or increased due to light cattle and horse grazing. These data also suggest that Artemisia dracunculus, A. ludoviciana, Erigeron speciosus, Solidago decumbens, Stellaria jamesiana and especially Viguiera multiflora are not ranked as high as they might be by the U.S. Forest Service (1969) for these
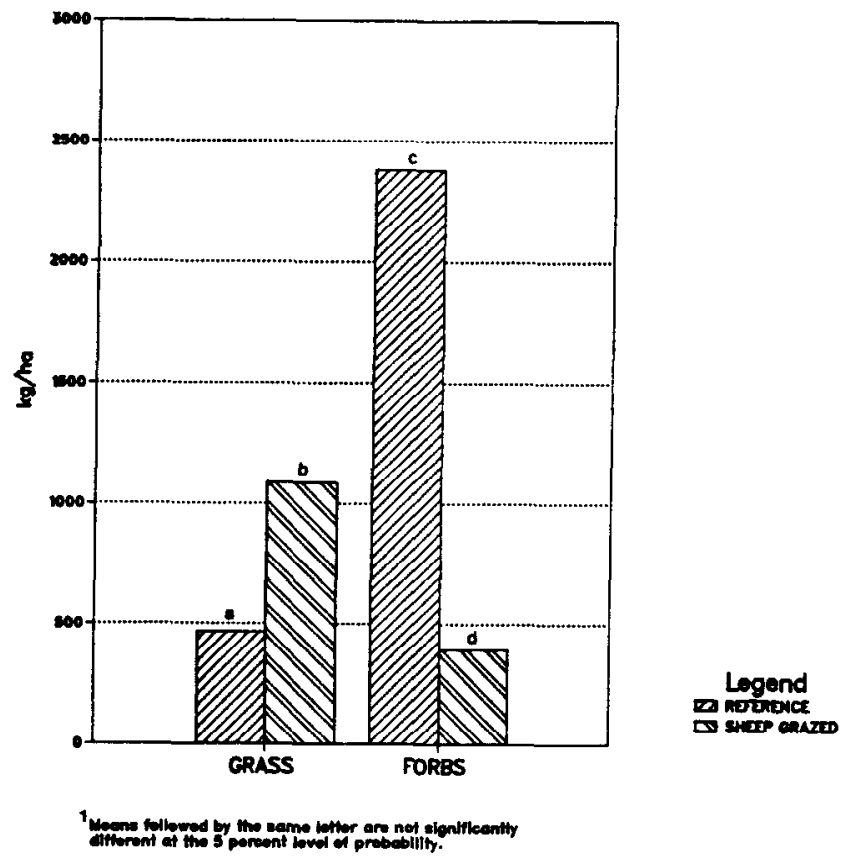

Fig. 4. Above-ground air dry biomass $(\mathrm{kg} / \mathrm{ha}$ ) of forbs and grasses within the sheep-grazed and the reference areas. southern Utah ranges. An upgrading of these would make the differences between categories more impressive than indicated in the previous discussion.

In the sheep-grazed pasture desirable species, mostly grasses, contributed $12 \%(173 \mathrm{~kg} / \mathrm{ha})$, intermediates $70 \%(1,207 \mathrm{~kg} / \mathrm{ha})$ and least desirables $19 \%(249 \mathrm{~kg} / \mathrm{ha})$ to the total above-ground biomass (Table 1, Fig. 3). The production of grasses $(1,086 \mathrm{~kg} / \mathrm{ha})$ was 2.8 times greater than forbs (393 kg/ha) (Fig. 4). Letterman needlegrass and Kentucky bluegrass contributed over $60 \%$ of the total above-ground biomass in the sheep-grazed pasture while these same species contributed only $15 \%$ in the reference area (Table 1 , Fig. 3).

Production of Kentucky bluegrass was essentially the same in the reference area $(312 \mathrm{~kg} / \mathrm{ha})$ as in the sheep-grazed pasture (303 $\mathrm{kg} / \mathrm{ha}$ ) and contributed $11 \%$ to the total above-ground biomass in the reference area but $20 \%$ in the sheep-grazed pasture. These data suggest that Kentucky bluegrass is more important as a component of these high elevation ranges than is sometimes assumed (U.S. Forest Service 1969). This grass is extremely palatable to both cattle and sheep in this region and is tolerant of heavy grazing (Bowns, data on file).

Mountain brome and Letterman needlegrass were more abundant in the sheep-grazed pasture than in the reference area. These data suggest that these 2 species and, to a lesser degree, slender wheatgrass increase under sheep grazing or decrease under light cattle and horse grazing. Letterman needlegrass has been described as an aggressive increaser on these range sites (Parker et al. 1979).

Tarweed, an annual species of very low palatability, is the most abundant forb in the sheep-grazed pasture. This species has a very ubiquitious distribution and is avoided by livestock. Hull and Cox (1968) referred to a sticky substance which gives off a strong odor and accounts for the common name. Tarweed is the dominant plant on extensive areas of depleted but potentially productive rangelands in the western USA. Tarweed plants contain substances that inhibit normal germination and reduce the growth of intermediate wheatgrass in laboratory studies (Carnahan and Hull 1962). Tarweed may therefore retard the rate of succession on depleted rangelands in this study area.

\section{Density}

Within the reference area intermediate species had the highest average density ( 56.9 plants $/ 0.18 \mathrm{~m}^{2}$ ), followed in order by desirables (10.6) and least desirables (5.8). Density of forbs (39.2) was only slightly higher than grasses (34.2) (Table 2). The density of

Table 2. Plant densities (Plants/0.18m²) within the sheep-grazed and references areas by desirability classes, forbs and grasses.

\begin{tabular}{lcc}
\hline \hline & Sheep-grazed & Reference \\
\hline Desirable & $2.2^{\mathrm{a}}$ & $10.6^{\mathrm{b}}$ \\
Intermediate & $46.1^{\mathrm{c}}$ & $56.9^{\mathrm{c}}$ \\
Least Desirable & $69.8^{\mathrm{d}}$ & $5.8^{\mathrm{a}}$ \\
Grasses & $41.4^{\mathrm{a}}$ & $34.2^{\mathrm{a}}$ \\
Forbs & $76.8^{\mathrm{b}}$ & $39.2^{\mathrm{ac}}$ \\
\hline
\end{tabular}

1Comparisons are made between grazing treatments and between desirability classes or between grasses and forbs. No comparisons are made between grasses and forbs and desirability classes. Means followed by the same letter are not significantly different at the $5 \%$ level of probability.

desirable species was 4.5 times higher in the reference area than in the sheep-grazed pasture.

In sheep-grazed pasture least desirables (69.8) has the highest densities followed by intermediates (46.1) and desirables (2.2). The higher density of least desirable species in the sheep-grazed pasture is due to the large number, small size, and ubiquitous distribution of undesirable annuals such as tarweed (54.8) and knotweed (12.8). In the reference area these species had density values of only 0.02 and 2.1 respectively. Kentucky bluegrass was responsible for the 
high density values of intermediate species in the sheep-grazed pasture (34.6) and the reference area (31.8). The rhizomatous nature of this grass accounts for these high values. The density of grasses in the sheep-grazed pasture (41.4) was significantly higher than in the reference area (34.2). Forb density in the sheep-grazed area (76.8) was, however, statistically higher than in the reference area (39.2) (Table 2).

\section{Summary}

An area dominated by tall forbs provides a striking contrast to the grass-dominated ranges surrounding it. This area is considered quasirelict and we feel represents potential or near potential natural vegetation for this range site. The difference between the forband grass-dominated areas is assumed to be a result of livestock grazing. The surrounding pastures have had a long and persistent history of sheep grazing while the reference area has received light grazing by a few cattle and horses. It is proposed that selective sheep grazing has eliminated the forbs from the surrounding pastures and grasses have subsequently increased.

\section{Literature Cited}

Camahan, G., and A.C. Hull. 1962. The inhibition of seeded plants by tarweed. Weeds 10:87-90.

Cottam, W.P. 1947. Is Utah Sahara bound? Tenth Annual Reynolds Lecture. Our renewable wild lands-a challenge. Univ. of Utah Press, Salt Lake City.

Dowdy, S., and S. Wearden. 1983. Statistics for research. John Wiley and Sons. New York.

Ellison, L. 1954. Subalpine vegetation of the Wasatch Plateau, Utah. Ecol. Monog. 24:89-184.

Hull, A.C., and H. Cox. 1968. Spraying and seeding high elevation tarweed rangelands. J. Range Manage. 21:140-144.

Jones, Y.F., and E.K. Jones. 1972. Lehi Willard Jones 1854-1947. Woodruff Printing Co., Salt Lake City, Utah.

Parker, K.G., L.R. Mason, and J.F. Vallentine. 1979. Utah grasses. Coop. Ext. Ser. Cir. 384. Utah State Univ., Logan.

U.S. Forest Service. 1969. Range environmental analysis handbookIntermountain Region. USDA Forest Service.

Welsh, S.L., and G. Moore. 1973. Utah plants. 3rd ed. Brigham Young Univ. Press, Provo, Utah. 